de Direito Processual

\title{
A Antecipação da Tutela Baseada no Abuso do Direito de Defesa: A Contribuição de Calmon de Passos
}

\author{
Preliminary Injunction Based on the Abuse of the Right of Defence: The Contribution of \\ Calmon de Passos
}

Rogéria Fagundes Dott ${ }^{1}$

${ }^{1}$ Universidade Federal do Paraná - UFPR, Brasil

\section{Resumo}

\begin{abstract}
O presente artigo procura relembrar lições do professor J.J. Calmon de Passos em relação à tutela provisória baseada no abuso do direito de defesa. Ele aborda a tutela da evidência no sistema anterior e no Código de Processo Civil de 2015. Analisa ainda a efetividade do processo mediante a antecipação.
\end{abstract}

Palavras-chave: Tutela provisória; Tutela da evidência; Abuso do direito de defesa e antecipação da tutela; Duração razoável do processo; Efetividade; Art; 311 do Código de Processo Civil de 2015

\begin{abstract}
This paper seeks to recall Professor J.J. Calmon de Passos' lessons, regarding the provisional remedy based on the abuse of the right of defense. It focuses on the relief based on clear right on the previous procedural system and on the Civil Procedure Code of 2015. It analyses the effectiveness of the procedure by preliminary injunction.

Keywords: Provisional remedy; Relief based on clear right; Abuse of the right of defence and preliminary injunction; Reasonable length of the procedure; Effectiveness; Article 311 of the Civil Procedure Code 2015
\end{abstract}

\section{O agradecimento a quem abre o caminho, ajudando a pensar}

O Prof. Calmon de Passos contribuiu de forma significativa à doutrina da tutela provisória no Brasil. Não há qualquer dúvida a esse respeito. Mas, além das importantes lições de direito, há um ensinamento especial que merece ser destacado. Ele consiste na forma com que o grande professor e jurista encarava a contribuição dos que o precederam. A nobreza dessa atitude é facilmente percebida por meio da gratidão que demonstrou na vida acadêmica.

Na abertura de seus Comentários ao Código de Processo Civil, publicado em 1984, ele fez um notável registro. Alertou que nós só realizamos, hoje, o que foi também semeado ontem, por muitos. Geralmente esquecemos os que nos ajudaram a chegar onde chegamos ${ }^{\text {. }}$

Salientou, por outro lado, que enumerar todos seria demasiado e perigoso, pelo risco das omissões. Por isso, escolheu fazer esse agradecimento nas pessoas de três amigos: Galeno Lacerda, Humberto Theodoro Junior e Ovídio Baptista da Silva. Disse, então:

1 CAlmon de PASSOS, José Joaquim. Comentários ao Código de Processo Civil, vol. X, Tomo I, arts. 796 a 812 , São Paulo: Editora Revista dos Tribunais, 1984, destaques nossos. 
Ao talento dos três, o meu muito obrigado. Quando deles divergi, só pude fazê-lo porque me abriram caminho, ajudando-me a pensar ${ }^{2}$.

Seguindo seu exemplo, o presente artigo inicia justamente com um sincero agradecimento. Agora é a nossa vez de agradecer ao Professor Calmon de Passos por ter, acima de tudo, aberto o caminho e nos ajudado a pensar.

\section{O abuso do direito de defesa: inconsistência, desvio de finalidade e litigância de má-fé}

Ao tratar da antecipação da tutela, sob a égide do sistema do Código de 1973, Calmon de Passos analisou a alteração decorrente da Lei nº 8.952/94, com a criação do art. 273, II e a consequente dispensa do periculum in mora. Como passou a prever a lei, havendo abuso no direito de defesa ou manifesto propósito protelatório do réu, seria possível a antecipação dos efeitos da tutela final.

O tratamento legal dado à conduta abusiva, especialmente no que diz respeito à tutela provisória, constituem o foco do presente trabalho. Uma das justificativas para essa escolha decorre do fato do Código de 2015, não apenas ter repetido tal previsão, como tê-la mantido praticamente intacta, tal qual admitida anteriormente. Outra, ainda mais relevante, consiste na indagação acerca das razões pelas quais a regra vem sendo tão pouco aplicada. Nesse aspecto, a doutrina do grande jurista baiano tem muito a contribuir.

O abuso do direito, na visão de Calmon de Passos, é algo amplo. Isso é de grande importância para uma aplicação mais genérica da tutela da evidência. O inciso II do art. 273 no sistema anterior e o atual inciso I do art. 311 do Código de 2015 revelam a existência de uma cláusula geral de antecipação sempre que houver defesa abusiva.

Mas afinal, quando se pode considerar que o réu praticou abuso em suas manifestações?

De acordo com Calmon de Passos, uma das formas do abuso consiste na defesa carecedora de consistência nos pontos fundamentais ${ }^{4}$. Isto é a defesa frágil, inconsistente. Trata-se de uma manifestação sem força argumentativa para afastar as alegações apresentadas pelo autor. Essa ideia de falta de seriedade na contestação é o que autoriza a antecipação sem urgência na França. Lá, a tutela da evidência pode ser concedida sempre que a obrigação não for seriamente contestável, conforme prevê o art. 809 do Code de Procédure Civile ${ }^{5}$.

Tal inconsistência pode se relacionar, segundo Calmon de Passos, tanto com os elementos de fato, quanto com a matéria de direito.

Existe, portanto, fragilidade nas situações em que a defesa não consegue tornar controvertidas as alegações de fato. Ou seja, o objeto da prova não se insere, verdadeiramente, em uma controvérsia judicial. A probabilidade do direito parece pender muito mais para o lado de uma das partes do que para o outro.

De igual forma, haveria falta de consistência quando, em matéria de direito, as alegações não constituíssem o denominado erro inescusável. Nesse ponto, o próprio jurista esclarece que esse consiste

2 CALMON DE PASSOS, José Joaquim. Comentários ao Código de Processo Civil, vol. X, Tomo I, arts. 796 a 812, São Paulo: Editora Revista dos Tribunais, 1984.

3 O abuso do direito de defesa não se refere apenas às manifestações ocorridas no momento da contestação, mas também a todo e qualquer ato defensivo, seja ele manifestado na defesa stricto sensu ou em incidentes processuais e recursos. A noção de defesa aqui é mais ampla do que o sentido estrito da impugnação específica às alegações da petição inicial. Logo, em qualquer momento do processo, inclusive após a prolação da sentença, será possível constatar o abuso no direito de defesa.

4 CALMON DE PASSOS, José Joaquim. Inovações no código de processo civil, Rio de Janeiro: Forense, 1995 , p. 19.

5 Art. 809. (Segunda parte). Dans les cas où l'existence de l'obligation n'est pas sérieusement contestable, il peut accorder une provision au créancier ou ordonner l'execution de l'obligation même s'il s'agit d'une obligation de faire. 
no erro sem justificativa doutrinária, jurisprudencial ou dogmática séria ${ }^{6}$. Para Calmon de Passos, a defesa carece de consistência quando são inconsistentes as alegações de fato ou as alegações de direito ${ }^{7}$.

Mas, a partir dessa ideia, surge uma indagação: basta a inconsistência para caracterizar o abuso? Em outras palavras, toda defesa frágil é abusiva?

Embora Calmon de Passos identifique abusividade na conduta descrita no art. 14, III do Código de 1973 (pretensão ou defesa destituídas de fundamento), ele mesmo acaba por agregar, à sua noção de abuso, o desvio de finalidade. Dessa forma talvez a melhor maneira de definir o abuso de direito seja dizer-se que ele ocorre quando se exercita, além do limite necessário, o direito que se tem, ou quando esse exercício objetiva não alcançar a tutela que a ele se associa e é devida a seu titular, sim outro fim, mesmo lícito que seja ou moralmente justificável . $^{\text {. }}$

Com efeito, a ideia da utilização indevida da oportunidade de defesa mostra-se central em sua concepção do abuso do direito de defesa. Em suas palavras, todo desvio de finalidade é um abuso 9 .

Observe-se que o desvio de finalidade acaba por gerar uma maior duração do processo, justamente porque cria obstáculos à célere prestação jurisdicional. Daí a relevância dessa concepção para autorizar a antecipação da tutela.

A doutrina italiana identifica na demora processual dois fenômenos distintos. Um deles decorre do tempo normal e necessário para a aferição da existência do direito. Outro advém justamente da defesa abusiva, a qual cria um problema adicional, referente ao prolongamento malicioso do tempo processual. Aparece então a lentezza patologica ${ }^{10}$, a qual deve ser combatida pelas sanções previstas no ordenamento. Trata-se da também denominada morosidade funcional ${ }^{11}$, provocada por uma das partes, ou em seu nome e na defesa dos seus interesses.

As expressões durata fisiologica e lentezza patologica são utilizadas por Proto Pisani para distinguir os dois fenômenos de demora processua ${ }^{12}$. Adverte, assim, que os obstáculos gerados por esse último demonstram a falência do Estado e sua explícita renúncia em fornecer a contrapartida decorrente da vedação à justiça privada. Essa situação pode e deve ser evitada. Vale lembrar o alerta de Calamandrei de que, em cada processo, diante da parte que tem pressa existe a outra, que pretende ir devagar. Normalmente é o autor quem tem pressa, percebendo-se no réu o interesse de alongar o máximo possível o acerto de contas ${ }^{13}$. Afinal, o tempo é fator que representa um enriquecimento sem causa para o litigante beneficiado pela morosidade na prolação da decisão judicial ${ }^{14}$.

Por outro lado, tal antinomia entre certeza e celeridade constitui um convite para soluções criativas e inovadoras, a partir das técnicas processuais. Isso inclui, sempre que possível, considerar a antecipação da tutela e ao mesmo tempo respeitar o contraditório prévio ${ }^{15}$. A adoção dessa técnica 6 CALMON DE PASSOS, José Joaquim. Inovações no código de processo civil, Rio de Janeiro: Forense, 1995, p. 18 e 19.

7 CALMON DE PASSOS, José Joaquim. Inovações no código de processo civil, Rio de Janeiro: Forense, 1995 , p. 19.

8 CALMON DE PASSOS, José Joaquim. Inovações no código de processo civil, Rio de Janeiro: Forense, 1995 , p. 19.

9 CALMON DE PASSOS, José Joaquim. Inovações no código de processo civil, Rio de Janeiro: Forense, 1995 , p. 19.

10 Andrea Proto Pisani distingue assim a durata fisiologica da durata patologica dos processos. (PROTO PISANI, Andrea. Appunti sulla tutela cautelare nel processo civile, in Rivista di Diritto Civile, Padova: Cedam, 1987, p. 112).

11 SANTOS, Boaventura de Sousa; MARQUES, Maria Manuel Leitão; PEDROSO, João; FERREIRA, Pedro Lopes. Os tribunais nas sociedades contemporâneas: o caso português. 2ª edição, Porto: Edições Afrontamento, 1996 , p. 432.

12 Nesse sentido, vide PROTO PISANI, Andrea. Appunti sulla tutela cautelare nel processo civile, in Rivista di Diritto Civile, Padova: Cedam, 1987, p. 111 e 112.

13 "In ogni processo accade quasi sempre che, di fronte alla parte che ha fretta, ci sia quella che vuole andare adagio: di solito chi ha fretta è l'attore, e chi non l'há è il convenuto, interessato ad allontanar più che può la resa dei conti”. (CALAMANDREI, Piero. Il processo come giuoco. In: Rivista di Diritto Processuale. v. V, parte I. Padova: Cedam - Casa Editrice Dott. Antonio Milani, 1950, p. 35).

14 ARRUDA, Samuel Miranda. O direito fundamental à razoável duração do processo, Brasília: Brasília Jurídica, 2006, p. 127.

15 DOTTI, Rogéria Fagundes. Tutela da evidência: probabilidade, defesa frágil e o dever de antecipar a tempo. São Paulo: Thomson Reuters Brasil, 2020, p. 34 e 35. 
permite evitar o excesso em sua dupla forma: o excesso do muito pouco (trop peu) e o excesso do muito cheio $(\text { trop plein })^{16}$.

Além da inconsistência e do desvio de finalidade, também seria abusiva a defesa que refletisse qualquer uma das condutas descritas nos incisos do art. 17 do Código de 1973, ou seja, as hipóteses de litigância de má-fé.

Nesse aspecto, Calmon de Passos equipara os fenômenos processuais da defesa abusiva e da litigância de má-fé. Esclarece que o dispositivo legal, ao prever a má-fé processual, trata de uma forma típica de abuso do direito de defesa. Logo, uma vez antecipada a tutela com base no abuso do direito ou no intuito protelatório, isso implicaria no reconhecimento da litigância de má-fé.

\section{A contribuição de Calmon de Passos: a imperativa aplicação das sanções processuais nos casos de litigância de má-fé}

Como exposto, na visão do mestre, os dispositivos do Código de Processo Civil, que prevêem a litigância de má-fé, constituem formas típicas de abuso do direito de defesa. O que se deve entender por abuso do direito de defesa? $O$ art. 17 do Código de Processo Civil enumera, em seis incisos ${ }^{17}$, as situações que tipifica como caracterizadoras da má-fé do litigante. E, ao mencionar a dedução de defesa contra texto expresso de lei, afirma que esta constitui, sem dúvida, uma forma típica de abuso do direito de defesa ${ }^{18}$.

Daí porque, em sua visão, sempre que houver a antecipação com base no alegado abuso, estarse-á reconhecendo a litigância de má-fé do réu.

Tal raciocínio leva a outra conclusão, de grande importância: a má-fé processual deve ser combatida de forma mais eficiente pelo Poder Judiciário, mediante a aplicação das sanções processuais previstas na legislação.

A recomendação acima tem enorme importância, não apenas para a obtenção de condutas processuais mais adequadas, mas também para a própria efetividade do processo. Isso porque, ao se evitar a conduta abusiva, combate-se a já referida duração patológica do processo.

Partindo da equiparação entre defesa abusiva e litigância de má-fé, Calmon de Passos destaca ainda o dever dos magistrados de condenação ao pagamento da multa e à indenização das perdas e danos. Por outro lado, entendo que, requerida a antecipação com base em abuso de direito ou intuito protelatório, deferida a antecipação, isso implica o reconhecimento da litigância de má-fé, pelo que a imposição da sanção prevista no art. 18 do Código de Processo Civil se faz imperativa ${ }^{19}$.

Saliente-se, nesse aspecto, que o Código de Processo Civil de 2015, no art. 81, manteve o dever do magistrado, de ofício ou a requerimento, condenar o litigante de má-fé. Mas foi além: majorou a multa, que antes deveria ser não excedente a um por cento do valor da causa, para o valor entre um por cento e dez por cento do valor da causa.

Ocorre que as sanções pela litigância de má-fé continuam a ser extremamente raras. Em relação ao Código de 1973, já se identificava uma timidez dos juízes na aplicação das sanções processuais previstas no ordenamento jurídico ${ }^{20}$. Ainda que a litigância de má-fé estivesse comumente presente,

16 A doutrina francesa preocupa-se com a gestão do tempo no processo. Nesse sentido, destaca-se o alerta feito pela Professora Marie-Anne Frison-Roche: "Ce sont deux notions-cadre qui visent à sanctioner l'excès sous ces deux formes: l'excès du trop peu et l'excès du trop plein". FRISON-ROCHE, Marie-Anne. Les droits fondamentaux des justiciables au regard du temps dans la procédure, in Le temps dans la procédure, Paris: Dalloz, 1996, p. 22.

17 O Professor Calmon de Passos se refere ao Código de Processo Civil de 1973, antes da alteração que incluiu o inciso VII (interposição de recurso com intuito manifestamente protelatório), o qual foi acrescentado pela Lei nº 9.668/98).

18 CALMON DE PASSOS, José Joaquim. Inovações no código de processo civil, Rio de Janeiro: Forense, 1995 , p. 18 e 19.

19 CALMON DE PASSOS, José Joaquim. Inovações no código de processo civil, Rio de Janeiro: Forense, 1995 , p. 20.

20 NEVES, Daniel Amorim Assumpção. Tutela Antecipada Sancionatória, in Revista Dialética de Direito Processual, vol. 43, Outubro 2006, p. 28. 
os dispositivos para combate-la eram pouco aplicados ${ }^{21}$. Dizia ainda haver uma certa complacência com as medidas procrastionatórias ${ }^{22}$ e até mesmo um subaproveitamento dos mecanismos de repressão de condutas retardatárias ou maliciosas ${ }^{23}$.

Acrescente-se ainda à realidade brasileira o problema cultural do arquétipo do homem cordial ${ }^{4}$, bem lembrado por Luiz Guilherme Marinoni. Com efeito, inserido no contexto do patrimonialismo brasileiro, o homem cordial, vestido de parte, advogado ou juiz, evidentemente inviabilizou a aplicação igualitária da lei, uma vez que essa deveria ser neutra e abstrata apenas àquele que não tivesse "boas razões" - ou seja, que não participasse do "círculo intimo" - para ser tratado de forma individualizada ${ }^{25}$. Como também esclarece Erik Navarro Wolkart, em nosso país, a subjetividade patrimonialista impede a impessoalidade das relações profissionais e, nesse aspecto, a postura punitiva cria atritos que são incompatíveis com as delícias da cordialidade ${ }^{26}$.

Essa timidez não constitui um fenômeno exclusivamente brasileiro. Outros sistemas, como o de Portugal, também sofrem com a resistência de juízes e tribunais em aplicar sanções processuais. Tratase de um excesso de garantismo, fruto da preocupação daqueles que se formaram em um ambiente em que era necessário garantir as pessoas contra as medidas tomadas pelo poder, aí se incluindo os tribunais ${ }^{27}$. Como alerta António Menezes Cordeiro, perante a tríade "garantismo", "astúcia das partes"e "timidez do tribunal", os processos soçobram nos muitos milhares de páginas inúteis, onde se esvaem a riqueza das partes e as energias do Poder Judiciales.

Daí a importância da posição de Calmon de Passos ao destacar o deverjudicial de punir a litigância de má-fé com a imposição das sanções processuais.

\section{O abuso, por si só, não é suficiente para a antecipação. A dança em sincronia entre abuso e probabilidade}

Alinhado à melhor doutrina, Calmon de Passos também entendia que o abuso de defesa não autorizaria, por si só, a antecipação da tutela. A este abuso deveria estar agregada a probabilidade do direito.

21 A propósito, Gilberto Bruschi convoca os advogados e juízes a aplicarem os dispositivos contra a litigância de má-fé: "Aproveitamos a oportunidade, ao aventar tal assunto, para sugerir aos advogados que, ao perceberem a conduta ardilosa da parte contrária, não só requeiram a antecipação de tutela prevista no inc. II do art. 273 do CPC, pois é vedada sua concessão ex officio pelo magistrado, como também postulem aos julgadores que se utilizem mais do instituto da litigância de má-fé, comumente presente nos processos e infelizmente pouquíssimo aplicado". (BRUSCHI, Gilberto. A tutela antecipada e a postura do juiz diante do pedido liminar - a possibilidade de sua concessão antes da citação do réu visando dar maior efetividade ao processo. In: MEDINA, José Miguel Garcia; CRUZ, Luana Pedrosa de Figueiredo; CERQUEIRA, Luís Otávio Sequeira de; GOMES JUNIOR, Luiz Manoel. Os poderes do juiz e o controle das decisões judiciais: estudos em homenagem à Professora Teresa Arruda Alvim Wambier, São Paulo: Editora Revista dos Tribunais, 2008, p. 432).

22 O alerta foi feito, dentre outros, por Humberto Theodoro Júnior: "Há sanções, no CPC brasileiro, para a conduta abusiva, em todos os tipos de processo, sanções que são especificamente instituídas e que são efetivamente aplicadas pelos juízes e tribunais, embora se tenha de reconhecer que tal só ocorra em volume inferior ao das violações, na verdade verificadas. Há uma certa complacência com as medidas procrastinatórias, em virtude de ser a ineficiência dos serviços forenses a maior e mais notória causa do retardamento da tutela jurisdicional no País". (THEODORO JÚNIOR, Humberto. Abuso de direito processual no ordenamento jurídico brasileiro, in Abusos dos direitos processuais / coordenador José Carlos Barbosa Moreira, Rio de Janeiro: Forense, 2000, p. 126).

23 GAJARDONI, Fernando da Fonseca. Técnicas de aceleração do processo. São Paulo: Lemos \& Cruz, 2003, p. 198.

24 Refere-se aqui à expressão utilizada por Sérgio Buarque de Holanda, na obra Raízes do Brasil, de 1936.

25 MARINONI, Luiz Guilherme. A Ética dos Precedentes, 1 ed., São Paulo: Editora Revista dos Tribunais, 2014 , p. 87.

26 WOLKART, Erik Navarro. Análise econômica do processo civil: como a economia, o direito e a psicologia podem vencer a tragédia da justiça. São Paulo: Thomson Reuters Brasil, 2019, p. 561 e 562.

27 CORDEIRO, António Menezes. Litigância de má-fé, abuso do direito de ação e culpa in agendo, 3 ed., aumentada e atualizada à luz do Código de Processo Civil de 2013, Coimbra: Almedina, 2016, p. 23 e 24.

28 CORDEIRO, António Menezes. Litigância de má-fé, abuso do direito de ação e culpa in agendo, 3 ed., aumentada e atualizada à luz do Código de Processo Civil de 2013, Coimbra: Almedina, 2016, p. 26. 
Ao comentar o art. 273, II do Código de 1973, afirmava não se tratar de algo que devesse ser somado ao risco de dano, mas sim algo que, por si mesmo e desde que presente a prova inequívoca, legitimava a antecipação. Em suas palavras, antecipa-se, apenas, para evitar o dano ou para se sancionar o abuso de direito ou a litigância temerária, mas para que uma coisa ou outra seja possível exige-se, sempre, prova inequívoca da alegação que constitui a causa de pedir na demanda ${ }^{29}$.

Isso significa que, apesar da omissão na lei anterior (art. 273, II do CPC/73) e no próprio inciso I do art. 311 do CPC/2015, a tutela antecipada está sempre vinculada à probabilidade. Com efeito, não faz sentido conceber-se a tutela provisória sem a presença de tal requisito. Isso porque, independentemente de qual seja a atitude do réu, não é juridicamente desejável antecipar um direito que não se mostre provável. A técnica da antecipação consiste justamente em um tratamento diferenciado, baseando-se no pressuposto de que determinado direito será reconhecido ao final. Se assim não fosse, não haveria razões para a antecipação.

Por outro lado, parece difícil haver o reconhecimento do abuso por parte do réu sem que, ao mesmo tempo, se conclua pela probabilidade do direito do autor. Nesse sentido, Eduardo Talamini afirma que o abuso pressupõe a constatação da extrema probabilidade do direito do autor pois, para que se possa qualificar a conduta como abusiva ou protelatória, é preciso que exista um juízo de plausibilidade bastante intenso acerca de quem tem razão $0^{30}$. Esse é o entendimento também de Humberto Theodoro Junior, para quem o abuso do direito de defesa ou a prática de ato processual imbuído de manifesto propósito protelatório acaba por reforçar a plausibilidade do direito ${ }^{31}$.

Assim, pode-se dizer que abuso do direito de defesa e probabilidade do direito agem em uma verdadeira dualidade, criando um desenho conjunto. $\mathrm{O}$ que se percebe, para utilizar uma imagem esclarecedora, é o de uma dança conjunta e em absoluta sincronia entre probabilidade e abuso. O movimento de um interfere no movimento do outro ${ }^{32}$.

\section{Antecipação de tutela com intuito punitivo?}

Ainda que seja possível constatar o abuso do direito de defesa nas hipóteses de litigância de máfé, parte da doutrina considera que a essência dessa forma de antecipação de tutela não é punitiva. Isto porque, quando o legislador permite a aplicação dessa técnica diante do abuso (art. 311, I do CPC/2015), o foco parece ser justamente o autor, cujo provável direito se encontra em situação que merece um tratamento diferenciado. Mais do que olhar para a conduta do réu, o legislador voltou seus olhos para o direito do autor.

Essa é a posição de Daniel Mitidiero, ao afirmar que não é punitiva a natureza da tutela. ${ }^{33}$ Para ele, a doutrina que propõe a interpretação da antecipação em caso de abuso como um expediente para realização da igualdade substancial dos litigantes é mais consentânea aos direitos fundamentais processuais do que aquela que encara o dispositivo como uma sanção ${ }^{34}$. Com efeito, em que pese destacados processualistas afirmarem que há um caráter punitivo ${ }^{35}$ (sendo absolutamente respeitáveis tais posições), essa não

29 CALMON DE PASSOS, José Joaquim. Inovações no código de processo civil, Rio de Janeiro: Forense, 1995 , p. 17.

30 TALAMINI, Eduardo. Medidas urgentes (“cautelares” e “antecipadas”): a Lei 10.444/2002 e o início de correção de rota para um regime jurídico único, in Revista Dialética de Direito Processual, n. 02, maio de 2003, p. 19.

31 TheOdORO JUNIOR, Humberto. Curso de Direito Processual Civil - Teoria geral do direito processual civil, processo de conhecimento e procedimento comum, v. I, 57. ed. rev. atual. e ampl. Rio de Janeiro: Forense, 2016 , p. 694.

32 A respeito da dança em sincronia entre a defesa abusiva e a probabilidade do direito, vide DOTTI, Rogéria Fagundes. Tutela da evidência: probabilidade, defesa frágil e o dever de antecipar a tempo. São Paulo: Thomson Reuters Brasil, 2020, p. 241.

33 MITIDIERO, Daniel, Antecipação da tutela. $3^{\mathrm{a}}$ ed, rev. atual. e ampl., São Paulo: Editora Revista dos Tribunais, 2017, p. 158.

34 MITIDIERO, Daniel. Tutela antecipatória e defesa inconsistente, in Tutela de urgência e cautelares: Estudos em homenagem a Ovídio A. Baptista da Silva/ coordenador Donaldo Armelin, São Paulo: Saraiva, 2010 , p. 339.

35 Nesse sentido, ou seja, entendendo que há um caráter sancionatório: DINAMARCO, Cândido Rangel. Instituições de direito processual civil: v. III, 7. ed. rev. e atual., São Paulo: Malheiros Editores, 2017, p. 884; NEVES, Daniel Amorim 
parece ser sua característica principal ${ }^{36}$. Afinal, se trata de técnica que visa impedir que aquele que tem razão seja prejudicado pelo tempo de instrução da causa ${ }^{37}$. Em outras palavras, o objetivo não é castigar o réu, mas sim beneficiar o autor que, aparentemente, tem um direito evidenciado. Evita-se, dessa forma, que ele seja prejudicado pela demora processual, criada maliciosamente pela parte contrária.

\section{O direito material e as medidas topologicamente cautelares: uma evidência fixada a priori pelo legislador}

Mas as lições de Calmon de Passos sobre tutela da evidência foram além da antecipação baseada no abuso. Ainda no sistema do Código de 1973, Calmon de Passos identificava situações em que o próprio legislador autorizava uma antecipação da realização do direito, independentemente dos requisitos de fumus boni juris e periculum in mora. Destacava, então, que não se tratavam de medidas cautelares, mas de medidas outras.

Esse raciocínio se mostra importante pois revela uma espécie de evidência do direito, a qual era antecipadamente prevista pela lei. Por exemplo, o art. 888, I dispunha sobre a autorização para a realização de obras em coisa litigiosa, enquanto que o inciso II dizia respeito ao direito à entrega de bens de uso pessoal do cônjuge e dos filhos. Parece claro que o que existe, nesses casos, é uma presunção da fragilidade da defesa do réu. Isto porque o mesmo não teria argumentos válidos para se opor à realização das obras de conservação ou à entrega dos bens que pertenciam ao cônjuge. Por sua vez, os incisos III, IV e V previam a guarda provisória dos filhos, o afastamento de menor autorizado a contrair casamento e o depósito de incapazes que sofriam castigos físicos ou morais. Em todas essas situações, o que se percebe é que a existência do direito do autor fica tão clara que justifica a antecipação. O mesmo pode se dizer quanto ao afastamento do cônjuge da morada do casal (inciso VI), à guarda e visita dos filhos, extensivo aos avós (inciso VII) e ainda à interdição ou demolição de prédio que gera risco à saúde, segurança ou qualquer outro interesse público (inciso VIII).

Assumpção. Tutela Antecipada Sancionatória, in Revista Dialética de Direito Processual, vol. 43, Outubro 2006, p. 19; LOPES, Bruno Vasconcelos Carrilho. Tutela antecipada sancionatória, São Paulo: Malheiros Editores, 2006, p. 55; BODART, Bruno V. da Rós. Tutela de evidência: teoria da cognição, análise econômica do direito processual e comentários sobre o novo CPC, $2^{\text {a }}$ ed, rev. atual. e ampl, São Paulo: Editora Revista dos Tribunais, 2015, p. 114 e 115; BEDAQUE, José Roberto dos Santos, Tutela cautelar e tutela antecipada: tutelas sumárias e de urgência (tentativa de sistematização), $5^{\mathbf{a}}$ ed, São Paulo: Malheiros Editores, 2009, p. 357; BEDAQUE, José Roberto dos Santos. In: BUENO, Cássio Scarpinella (Coord). Comentários ao código de processo civil, v. 1 (arts. $1^{\circ}$ a 317). São Paulo: Saraiva, 2017, p. 955; CÂMARA, Alexandre de Freitas. O novo processo civil brasileiro, 3a ed, rev. atual. e ampl., São Paulo: Atlas, 2017, p. 172; ARAÚJO, José Henrique Mouta. Coisa julgada progressiva \& resolução parcial do mérito: instrumentos de brevidade da prestação jurisdicional, Curitiba: Juruá, 2008, p. 295; ASSIS, Carlos Augusto de; LOPES, João Batista. Tutela Provisória: tutela antecipada; tutela cautelar; tutela da evidência; tutela inibitória antecipada. Brasília: Gazeta Jurídica, 2018, p. 170; DIDIER JUNIOR, Fredie; BRAGA, Paula Sarno; OLIVEIRA, Rafael Alexandria de. Curso de direito processual civil: teoria da prova, direito probatório, ações probatórias, decisão, precedente, coisa julgada e antecipação dos efeitos da tutela. 11. ed. Salvador: Editora Jus Podivm, 2016, p. 633.

36 Parte da doutrina, corretamente, afasta esse caráter sancionatório. Vide WAMBIER, Luiz Rodrigues; TALAMINI, Eduardo. Curso avançado de processo civil: cognição jurisdicional (processo comum de conhecimento e tutela provisória), v. 2, 16. ed. reformulada e ampliada de acordo com o novo CPC, São Paulo: Editora Revista dos Tribunais, 2016, p. 898. De igual forma THEODORO JÚNIOR, Humberto. Curso de Direito Processual Civil - Teoria geral do direito processual civil, processo de conhecimento e procedimento comum, vol. I, 57 $\underline{a}$ ed, rev. atual. e ampl, Rio de Janeiro: Forense, 2016, p. 694; GOUVEIA, Lúcio Grassi de. A dedução de pedido ou defesa contra texto expresso de lei ou fato incontroverso como hipótese de litigância de má-fé e a concessão da tutela provisória de evidência. In: Revista de Processo, vol. 264, fev/2017, p. 127-154. Nesse mesmo sentido, referindo-se ao art. 273, II do Código de Processo Civil: LUCON, Paulo Henrique dos Santos. Eficácia das decisões e execução provisória. São Paulo: Editora Revista dos Tribunais, 2000, p. 239; BRUSCHI, Gilberto. A tutela antecipada e a postura do juiz diante do pedido liminar - a possibilidade de sua concessão antes da citação do réu visando dar maior efetividade ao processo. In: MEDINA, José Miguel Garcia; CRUZ, Luana Pedrosa de Figueiredo; CERQUEIRA, Luís Otávio Sequeira de; GOMES JUNIOR, Luiz Manoel. Os poderes do juiz e o controle das decisões judiciais: estudos em homenagem à Professor Teresa Arruda Alvim Wambier, São Paulo: Editora Revista dos Tribunais, 2008 , p. 432.

37 MARINONI, Luiz Guilherme. Abuso de defesa e parte incontroversa da demanda, 2a ed, São Paulo: Editora Revista dos Tribunais, 2011, p. 58 
O liame que une todos esses exemplos é uma verdadeira antevisão do legislador, no sentido de que a eventual defesa do réu será sempre frágil e inconsistente.

A propósito, Calmon de Passos destacava que, mesmo na ausência de periculum in mora, a tais procedimentos era concedido o tratamento célere das medidas cautelares. Referia-se justamente ao disposto no art. 888 daquele diploma, destacando que se tratavam de processos topologicamente cautelares, mas que tinham seus princípios próprios e que, portanto, escapavam ao disposto na parte geral do processo cautelar $^{38}$. Enumerava assim a existência de medidas cautelares, medidas provisionais e medidas outras. As primeiras encerravam verdadeiras pretensões cautelares. As segundas, ditas provisionais, referiam-se ao dever judicial de prover a boa marcha do processo ou atender o interesse dos sujeitos que estavam sob a tutela judicial. E as medidas outras eram justamente as medidas substanciais, ou seja, aquelas voltadas ao atendimento dos interesses materiais dos sujeitos processuais, conexamente relacionados, ou não, ao interesse principal, objeto do processo $^{39}$.

No caso dessas medidas apenas topologicamente cautelares, a razão da tutela diferenciada residia no próprio direito material, cuja situação era previamente concebida pelo legislador como merecedora de uma maior celeridade e efetividade ${ }^{40}$.

No sistema do Código de Processo Civil de 2015, tais medidas podem ser equiparadas a outras formas de tutela da evidência, não previstas no art. 311. Exatamente nas situações em que o fundamento para antecipação (sem o requisito da urgência) é a peculiaridade do direito material.

Com efeito, nos casos em que a própria lei autoriza a concessão liminar sem urgência, o que se verifica é que o legislador antecipadamente pressupõe a evidência do direito, pela mera natureza da relação material envolvida. E isso se dá independentemente da conduta ou do comportamento do réu. Trata-se de uma concepção $a$ priori, fixada antes do desenrolar do processo. Nessas situações, em virtude desse entendimento genérico e abstrato da lei, e inobstante a ausência de periculum in mora, autoriza-se a antecipação liminar ${ }^{41}$.

A lei identifica nessas hipóteses a existência de peculiaridades da relação de direito material que autorizam medidas provisórias de caráter antecipatório, para elevar o grau de utilidade do suposto provimento final, que se apresenta altamente provável ${ }^{42}$. É o que verifica, por exemplo, nas ações possessórias (CPC, art. 462), nos embargos de terceiro (CPC, art. 678), nas ações de despejo por falta de pagamento quando o credor estiver desprovido de garantias como caução ou fiança (Lei no 8.245/91, art. 59, § 1º), nas ações revisionais de aluguel (Lei no 8.245/91, art. 68, II), na busca e apreensão de bem alienado fiduciariamente (DL no 911/1969) e na antecipação de uso e fruição de bem na partilha (CPC, art. 647, $\S$ único).

Tais medidas albergam providências, normalmente, de natureza satisfativa pois antecipam os efeitos da providência final desejada.

\section{Conclusão: a efetividade do processo a partir da transformação da realidade}

Na obra de Calmon de Passos, sempre foi clara a distinção entre a prestação da atividade jurisdicional (a que faz jus todo jurisdicionado) e a tutela jurídica (destinada apenas à parte a quem deva ser concedido

38 CALMON DE PASSOS, José Joaquim. Comentários ao Código de Processo Civil, vol. X, Tomo I, São Paulo: Editora Revista dos Tribunais, 1984, p. 55 e 56.

39 CAlmON DE PASSOS, José Joaquim. Comentários ao Código de Processo Civil, vol. X, Tomo I, São Paulo: Editora Revista dos Tribunais, 1984, p. 59.

40 DOTTI, Rogéria Fagundes. Tutela da evidência: probabilidade, defesa frágil e o dever de antecipar a tempo. São Paulo: Thomson Reuters Brasil, 2020, p. 199.

41 DOTTI, Rogéria Fagundes. Tutela da evidência: probabilidade, defesa frágil e o dever de antecipar a tempo. São Paulo: Thomson Reuters Brasil, 2020, p. 182.

42 BEDAQUE, José Roberto dos Santos. Tutela cautelar e tutela antecipada: tutelas sumárias e de urgência (tentativa de sistematização). (1998). 5. ed. rev. e ampl. São Paulo: Malheiros Editores, 2009, p. 365 e 366. 
o bem pleiteado $)^{43}$. Daí porque obter um provimento jurisdicional do Estado-juiz não é suficiente para assegurar tutela do direito. Esta exige a satisfação da pretensão de direito material. Dizia ele que integram a função jurisdicional o conhecer, o julgar e o efetivar o julgado; para usar palavras mais nobres ou mais doutas: notio, judicium et imperium, ou coexistem ou não existe poder jurisdicional ${ }^{44}$.

Essa concepção de um direito que deve operar resultados concretos está totalmente em harmonia com o disposto no art. $4^{\circ}$ do Código de 2015. Como prevê a lei atual, as partes têm o direito de obter em prazo razoável a solução integral do mérito, incluída a atividade satisfativa. Isso significa que não basta mais declarar o direito, é preciso realiza-lo concretamente.

Isso bem demonstra a preocupação do autor e professor com a efetividade do processo. Esclarecia ele que, havendo conflito entre os valores constitucionais da efetividade e do contraditório, este último deveria ser sacrificado provisoriamente, assegurando-se a antecipação da tutela. Trata-se da aplicação do princípio da proporcionalidade, que impõe o sacrifício de um bem jurídico, suscetível de tutela subsequente, em favor de outro bem jurídico que, se não tutelado de pronto, será definitivamente sacrificado ${ }^{45}$.

Sua visão de processo efetivo fica muito clara na seguinte passagem:

Enquanto puro pensamento, o direito ainda não é. O direito é no momento em que eficazmente dispõe sobre a realidade e nela opera as transformações desejadas ${ }^{46}$.

Tal lição deve permanecer entre nós a fim de que as normas processuais, especialmente da tutela da evidência, venham a ter uma maior aplicação prática, transformando o triste cenário de espera dos jurisdicionados.

\section{Referências}

ARAÚJO, José Henrique Mouta. Coisa julgada progressiva \& resolução parcial do mérito: instrumentos de brevidade da prestação jurisdicional, Curitiba: Juruá, 2008.

ARRUDA, Samuel Miranda. O direito fundamental à razoável duração do processo, Brasília: Brasília Jurídica, 2006.

ASSIS, Carlos Augusto de; LOPES, João Batista. Tutela Provisória: tutela antecipada; tutela cautelar; tutela da evidência; tutela inibitória antecipada. Brasília: Gazeta Jurídica, 2018.

BEDAQUE, José Roberto dos Santos. In: BUENO, Cássio Scarpinella (Coord). Comentários ao código de processo civil, v. 1 (arts. $1^{\circ}$ a 317). São Paulo: Saraiva, 2017.

Tutela cautelar e tutela antecipada: tutelas sumárias e de urgência (tentativa de sistematização), 5ª ed., São Paulo: Malheiros Editores, 2009,

BODART, Bruno V. da Rós. Tutela de evidência: teoria da cognição, análise econômica do direito processual e comentários sobre o novo CPC, $2^{a}$ ed., rev. atual. e ampl., São Paulo: Editora Revista dos Tribunais, 2015.

BRUSCHI, Gilberto. A tutela antecipada e a postura do juiz diante do pedido liminar - a possibilidade de sua concessão antes da citação do réu visando dar maior efetividade ao processo. In:

MEDINA, José Miguel Garcia; CRUZ, Luana Pedrosa de Figueiredo; CERQUEIRA, Luís Otávio Sequeira de; GOMES JUNIOR, Luiz Manoel. Os poderes do juiz e o controle das decisões

43 CALMON DE PASSOS, José Joaquim. Inovações no código de processo civil, Rio de Janeiro: Forense, 1995 , p. 05.

44 CALMON DE PASSOS, José Joaquim. Até quando abusarás, ó Catilina? Cautelares e liminares - catástrofe nacional, in Revista de Processo, vol. 71, Jul-Set.1993, p. 227-233.

45 CALMON DE PASSOS, José Joaquim. Inovações no código de processo civil, Rio de Janeiro: Forense, 1995 , p. 07.

46 CALMON DE PASSOS, José Joaquim. Comentários ao Código de Processo Civil, vol. X, Tomo I, arts. 796 a 812 , São

Paulo: Editora Revista dos Tribunais, 1984, p. 10. 
judiciais: estudos em homenagem à Professora Teresa Arruda Alvim Wambier, São Paulo: Editora Revista dos Tribunais, 2008.

CALAMANDREI, Piero. Il processo come giuoco. In: Rivista di Diritto Processuale. v. V, parte I. Padova: Cedam - Casa Editrice Dott. Antonio Milani, 1950.

CALMON DE PASSOS, José Joaquim. Até quando abusarás, ó Catilina? Cautelares e liminares catástrofe nacional, in Revista de Processo, vol. 71, Jul-Set.1993.

Comentários ao Código de Processo Civil, vol. X, Tomo I, arts. 796 a 812, São Paulo: Editora Revista dos Tribunais, 1984.

Inovações no código de processo civil, Rio de Janeiro: Forense, 1995.

CÂMARA, Alexandre de Freitas. O novo processo civil brasileiro, $3^{\mathfrak{a}}$ ed., rev. atual. e ampl., São Paulo: Atlas, 2017.

CORDEIRO, António Menezes. Litigância de má-fé, abuso do direito de ação e culpa in agendo, 3 ed., aumentada e atualizada à luz do Código de Processo Civil de 2013, Coimbra: Almedina, 2016.

DIDIER JUNIOR, Fredie; BRAGA, Paula Sarno; OLIVEIRA, Rafael Alexandria de. Curso de direito processual civil: teoria da prova, direito probatório, ações probatórias, decisão, precedente, coisa julgada e antecipação dos efeitos da tutela. 11. ed. Salvador: Editora Jus Podivm, 2016.

DINAMARCO, Cândido Rangel. Instituições de direito processual civil: v. III, 7. ed. rev. e atual., São Paulo: Malheiros Editores, 2017.

DOTTI, Rogéria Fagundes. Tutela da evidência: probabilidade, defesa frágil e o dever de antecipar a tempo. São Paulo: Thomson Reuters Brasil, 2020.

FRISON-ROCHE, Marie-Anne. Les droits fondamentaux des justiciables au regard du temps dans la procédure, in Le temps dans la procédure, Paris: Dalloz, 1996.

GAJARDONI, Fernando da Fonseca. Técnicas de aceleração do processo. São Paulo: Lemos \& Cruz, 2003.

GOUVEIA, Lúcio Grassi de. A dedução de pedido ou defesa contra texto expresso de lei ou fato incontroverso como hipótese de litigância de má-fé e a concessão da tutela provisória de evidência. In: Revista de Processo, vol. 264, fev/2017.

LOPES, Bruno Vasconcelos Carrilho. Tutela antecipada sancionatória, São Paulo: Malheiros Editores, 2006.

LUCON, Paulo Henrique dos Santos. Eficácia das decisões e execução provisória. São Paulo: Editora Revista dos Tribunais, 2000.

MARINONI, Luiz Guilherme. Abuso de defesa e parte incontroversa da demanda, 2ª ed., São Paulo: Editora Revista dos Tribunais, 2011.

A Ética dos Precedentes, 1 ed., São Paulo: Editora Revista dos Tribunais, 2014.

MITIDIERO, Daniel. Tutela antecipatória e defesa inconsistente, in Tutela de urgência e cautelares: Estudos em homenagem a Ovídio A. Baptista da Silva/ coordenador Donaldo Armelin, São Paulo: Saraiva, 2010.

Antecipação da tutela. $3^{\text {a }}$ ed, rev. atual. e ampl., São Paulo: Editora Revista dos Tribunais, 2017.

NEVES, Daniel Amorim Assumpção. Tutela Antecipada Sancionatória, in Revista Dialética de Direito Processual, vol. 43, Outubro 2006.

PROTO PISANI, Andrea. Appunti sulla tutela cautelare nel processo civile, in Rivista di Diritto Civile, Padova: Cedam, 1987. 
SANTOS, Boaventura de Sousa; MARQUES, Maria Manuel Leitão; PEDROSO, João; FERREIRA, Pedro Lopes. Os tribunais nas sociedades contemporâneas: o caso português. 2a edição, Porto: Edições Afrontamento, 1996.

TALAMINI, Eduardo. Medidas urgentes (“cautelares” e “antecipadas”): a Lei 10.444/2002 e o início de correção de rota para um regime jurídico único, in Revista Dialética de Direito Processual, n. 02, maio de 2003.

THEODORO JÚNIOR, Humberto. Abuso de direito processual no ordenamento jurídico brasileiro, in Abusos dos direitos processuais/ coordenador José Carlos Barbosa Moreira, Rio de Janeiro: Forense, 2000.

Humberto. Curso de Direito Processual Civil - Teoria geral do direito processual civil, processo de conhecimento e procedimento comum, vol. I, 57aㅡ ed., rev. atual. e ampl, Rio de Janeiro: Forense, 2016,

WAMBIER, Luiz Rodrigues; TALAMINI, Eduardo. Curso avançado de processo civil: cognição jurisdicional (processo comum de conhecimento e tutela provisória), v. 2, 16. ed. reformulada e ampliada de acordo com o novo CPC, São Paulo: Editora Revista dos Tribunais, 2016.

WOLKART, Erik Navarro. Análise econômica do processo civil: como a economia, o direito e a psicologia podem vencer a tragédia da justiça. São Paulo: Thomson Reuters Brasil, 2019. 